\title{
Distribution of Xylella fastidiosa in Sycamore Associated with Low Temperature and Host Resistance
}

T. S. M. Henneberger and K. L. Stevenson, Department of Plant Pathology, University of Georgia, Athens 306027274; K. O. Britton, United States Department of Agriculture Forest Service Southern Research Station, Athens, GA 30602-2044; and C. J. Chang, Department of Plant Pathology, University of Georgia, Georgia Experiment Station, Griffin 30223-1797

\begin{abstract}
Henneberger, T. S. M., Stevenson, K. L., Britton, K. O., and Chang, C. J. 2004. Distribution of Xylella fastidiosa in sycamore associated with low temperature and host resistance. Plant Dis. 88:951-958.

Experiments were conducted in the field and laboratory to determine effects of low temperatures on Xylella fastidiosa populations in American sycamore. Roots and shoots from naturally infected trees at two locations were collected monthly. Sap extracted from the samples was tested by enzyme-linked immunosorbent assay for presence of $X$. fastidos $a$ and was diluted and plated on periwinkle wilt medium to determine populations of viable bacteria. Cumulative rainfall and hours below temperature thresholds $\left(-5\right.$ to $\left.10^{\circ} \mathrm{C}\right)$ were recorded at each site. Bacterial populations in shoots were negatively correlated with cumulative hours below $-5^{\circ} \mathrm{C}$ air temperature $(r$ $=-0.96)$. In roots, bacterial populations were only weakly correlated with cumulative hours below soil temperature thresholds $(-0.61<r<-0.25)$. Bacterial populations were not correlated with monthly rainfall. In the laboratory, resistant and susceptible sycamore trees were inoculated with $X$. fastidiosa and held in the dark at $5^{\circ} \mathrm{C}$ or $22^{\circ} \mathrm{C}$. After 12 weeks, inoculated stem sections were collected and sap was extracted and tested as described previously. Stems that tested positive for X. fastidiosa were divided into additional samples and tested as described above. Results of the laboratory study indicated no significant effects of low-temperature treatment $\left(5^{\circ} \mathrm{C}\right)$ or host resistance on viable bacteria. Bacterial detection frequency and population size were greatest near the inoculation point and the primary direction of early bacterial spread was acropetal.
\end{abstract}

Additional keywords: mechanical inoculation, sycamore decline

The xylem-limited, endophytic bacterium, Xylella fastidiosa Wells et al. (28) has been reported to infect hosts from more than 30 families of monocots and dicots. The pathogen has been implicated as the cause of leaf scorch, decline, and dieback diseases of an increasing number of forest and ornamental trees, including elm (Ulmus spp.), maple (Acer spp.), oak (Quercus spp.), and sycamore (Platanus spp.) $(4,11,17,26)$. Diseases caused by $X$. fastidiosa in landscape and forest trees are characterized by development of foliar marginal necrosis in late summer and, in subsequent growing seasons in milder climates, by progressive basipetal decline and dieback (11).

Limited options are available for management of leaf scorch, decline, and dieback diseases of forest and ornamental trees. At present, the recommended strategies for managing diseases caused by $X$. fastidiosa on trees are use of resistant

Corresponding author: K. L. Stevenson

E-mail: ks@uga.edu

Accepted for publication 14 April 2004.

Publication no. D-2004-0625-01R

(C) 2004 The American Phytopathological Society plants where available, maintenance of stress-free plants, and removal of plants that become infected (21). Ubiquitousness of the sharpshooter leafhopper vectors (Homoptera, Cicadellidae) as well as their long season of activity negates the possibility of vector management $(12,13)$; no antibiotics or bactericides are commercially available for control of $X$. fastidiosa in landscape and forest trees (21); and, although a new breed of systemic-resistance-inducing chemicals have been labeled for this use, their effectiveness remains unproven.

Previous research on American sycamore has suggested that it may be a likely candidate for genetic improvement by selective breeding $(10,18,29)$. In a study examining optimization of production practices and breeding for mature biomass in Platanus occidentalis, Land determined that sycamores grown from seed from provenances south of the growing sites studied had significantly less disease incidence than those grown from seed collected from origins north of the test site after five to seven growing seasons under high disease pressure (18). Similarly, Wells and Toliver (29) reported sycamore height variations attributable to latitude of origin among a set of provenances from along the hot and droughty Gulf coast, but they failed to detect similar differences from a set of provenances located along the more temperate and rainy Mississippi River valley. Greene and Lowe (10) made similar correlations between increasing latitude of origin and increasing disease incidence and severity and decreasing height in their 15 -year study of $P$. occidentalis from seed sources within the western Gulf region. Both sets of researchers attribute negative height correlations to top dieback and crown loss resulting from stem canker infections caused by Ceratocystis fimbriata Ellis \& Halst. f. platani J. M. Walter and Botryosphaeria rhodina (Cooke) Arx; although, as understanding of sycamore decline and dieback improves, it has become clear that $X$. fastidiosa is a frequent precursor to these opportunistic stem canker diseases and causes considerable apical dieback and crown loss even before cankers appear (19). These results suggest that either decreased susceptibility due to heavy selection in more disease-pressured southern latitudes or increased direct or indirect damage to less cold-hardy host tissues of southern origin in northern latitudes may reduce disease in sycamore grown from seed from sources south of intended biomass planting sites.

Research on grape (Vitis spp.) has suggested the possible amelioration of infections caused by $X$. fastidiosa by exposure of plants to low temperatures sublethal to hosts but lethal to the bacterium $(8,22,23)$. Purcell reported that multiple exposures of 1.5 to $24 \mathrm{~h}$ to temperatures ranging from -12 to $0^{\circ} \mathrm{C}$ greatly enhanced the likelihood of survival of inoculated, symptomatic grapevines (22). In another study of grapevines vector-inoculated with $X$. fastidiosa, reported recovery rates for vines exposed to winter conditions at a variety of cold climates reached $100 \%$ in some more extreme environments (23). Studies of the temperature-dependent growth and survival of the pathogen both in vitro and in planta indicated that populations of $X$. fastidiosa decline at "cool but above-freezing temperatures" (8). Feil and Purcell reported that in vitro populations grew at $18^{\circ} \mathrm{C}$ but not $12^{\circ} \mathrm{C}$ and determined that the in planta minimum threshold temperature for growth in containerized grapevines was between 17 and $25^{\circ} \mathrm{C}(8)$.

Our objectives were to determine whether natural low temperatures in the 
field or low temperature treatment under controlled laboratory conditions would inhibit bacterial populations in naturally or artificially inoculated sycamores and yield reductions in disease similar to those observed in grape $(22,23)$, and to determine whether there was any difference between the effects of cold treatment on $X$. fastidiosa-resistant and -susceptible sycamore cultivars and those reported on resistant and susceptible cultivars of grape (23).

\section{MATERIALS AND METHODS}

Effects of low temperatures on bacterial populations in naturally infected sycamores in the field. Sample collection. The field study was replicated at two locations (Athens and Griffin, GA). Shoot and root tissue were sampled on a monthly basis, with sampling intervals ranging from 21 to 31 days, from 5 September 2001 to 16 September 2002. Three root and three shoot samples were collected from each of three sycamore trees at each location, a total of 18 samples per month from each location $(n=36)$. Samples were collected for 13 intervals, a 409-day span.

In Athens, trees were selected based on results of an earlier survey of sycamores in the area. In the prior survey, symptomatic and asymptomatic stem tissue was sampled from current and 1-year growth of 112 sycamores located on the University of Georgia Athens campus $(n=224)$. If trees did not exhibit typical scorching symptoms, two stem samples were arbitrarily chosen from each tree. After stem samples were surface disinfested, vacuum replacement extraction was conducted as described by French et al. (9) for each sample under laminar air flow using a vacuum pump to pull $3 \mathrm{ml}$ of polyvinylpyrrolidone (PVPP) extraction buffer (8.0 g of sodium chloride, $1.15 \mathrm{~g}$ of dibasic sodium phosphate [anhydrous], $0.2 \mathrm{~g}$ of monobasic potassium phosphate [anhydrous], $0.2 \mathrm{~g}$ of potassium chloride, $0.5 \mathrm{~g}$ of Tween-20, 2.0 $\mathrm{g}$ of $2 \%$ acid-washed PVPP 40,000 [PVP40], and $1,000 \mathrm{ml}$ of distilled water, $\mathrm{pH}$ adjusted to 7.4) through the stem segment and into a collection flask. Extracts were tested by a commercially available enzyme-linked immunosorbent assay (ELISA) (PathoScreen Xf peroxidase; Agdia, Elkhart, IN) to determine the presence of $X$. fastidiosa in sample tissue. Each sample was subjected to two plate replications, according to the manufacturer's instructions. Plates were evaluated on a microtiter plate reader (Model 550; Biorad, Hercules, CA) at an absorbance of $490 \mathrm{~nm}$ and scores were confirmed using microplate analysis software (Biorad Microplate Manager, v.5.1 for Windows; Biorad). To ensure that there would be large bacterial populations within the naturally infected tissue samples, three trees were selected on the basis of positive ELISA results with high absorbance readings $(>1.5)$, characteristic leaf scorch and marginal necrosis symptoms, and proximity to one another.

In Griffin, several trees were located and assessed for visible symptoms. Symptomatic stem tissue ( $1 \mathrm{~g}$ ) was sampled from current and 1-year growth on each tree. Vacuum-extracted xylem sap from each sample was tested by ELISA for confirmation of bacterial presence. Once infection was confirmed, three trees that had severe symptoms but not more than $40 \%$ dieback were selected.

All trees sampled at both locations were approximately 10 years of age or older. Diameter at breast height ranged from 15 to $65 \mathrm{~cm}$. All six trees sampled were well established ( $>2$ years) within their respective landscapes.

On each sampling date, three root and three shoot samples were collected from all trees at each location on the same day. During the growing season, $10-\mathrm{cm}$ or longer segments of current-season or 1year-old stem tissue (diameter $\leq 1.5 \mathrm{~cm}$ ) were preferentially sampled on the basis of presence of characteristic symptoms. Subsequent samples were collected from nearby or adjacent stems. Root segments (10 cm long, 0.5 to $2 \mathrm{~cm}$ in diameter) were collected by random excavation around the base of trees, in a zone approximately halfway between the trunk and canopy edge. Suitable roots were located at depths ranging from 2 to $25 \mathrm{~cm}$. Once roots were located, they were marked to permit sampling from the same roots in subsequent months. This method was not infallible, however; occasionally, grounds crews at both locations removed markers and new sample roots had to be located. Stem and root samples were placed in plastic bags and stored in a refrigerator at $5^{\circ} \mathrm{C}$ until processing. Samples were processed within $48 \mathrm{~h}$ after collection.

Pathogen detection and isolation. Any leaves present were removed manually from stem samples. Root samples were rinsed and scrubbed under tap water to remove excess soil. Root or stem segments (5 $\mathrm{g}$ each) were cut from each sample. Root and stem samples were surface disinfested for $10 \mathrm{~min}$ in a solution of $9.5 \%$ ethanol, $1.05 \%$ sodium hypochlorite, and deionized water. Samples were agitated on a shaker to ensure thorough coverage. Samples then were rinsed three times for 3 min in sterile, deionized water and transferred to a laminar flow hood for bacterial extraction.

Sap was extracted from surface-disinfested stem and root tissues by squeezing each section with pliers. Sap pressed from the cut face of the sample tissue was collected with a sterile glass capillary tube and expelled into a volumetric microcentrifuge tube with air from a sterile syringe. Total amounts of sap were recorded for each sample. Volumes extracted ranged from 0.129 to $0.346 \mathrm{ml}$. Sap from each sample $(100 \mu \mathrm{l})$ was diluted in sterile
PVPP extraction buffer in a fivefold series. Then, $10 \mu \mathrm{l}$ from each dilution was spread onto periwinkle wilt (PW) agar (4). Plates were maintained at $28^{\circ} \mathrm{C}$ and examined weekly until characteristic colony growth of $X$. fastidiosa was observed. Characteristic colonies were randomly tested by ELISA to confirm pathogen identity. Colonies of $X$. fastidiosa were counted and populations of bacterial CFU per unit mass of host tissue were determined for each sample. Bacterial population densities $(\mathrm{CFU} / \mathrm{g})$ were transformed as $\log (n+1)$, where $n=\mathrm{CFU} / \mathrm{g}$ of sample tissue, to stabilize variances. An additional $100 \mu \mathrm{l}$ of extracted sap was utilized for two ELISA replications to confirm the presence of $X$. fastidiosa and evaluated as previously described.

Weather data. Weather data from monitoring stations within $10 \mathrm{~km}$ of each location were obtained from the Georgia Automated Environmental Monitoring Network (Gerrit Hoogenboom, University of Georgia Department of Biological and Agricultural Engineering, Griffin). Air temperature, 5-, 10-, and 20-cm-deep soil temperature measurements, and rainfall $(\mathrm{mm})$ were recorded every $15 \mathrm{~min}$ and collected for the entire 409-day sampling period. The minimum air and soil temperature over the entire sampling period at both locations never dipped below $-10^{\circ} \mathrm{C}$ air temperature and $0^{\circ} \mathrm{C}$ soil temperature at any depth. Therefore, $5^{\circ}$ temperature increments were constructed above these minima. The air temperature data were used to generate mean and cumulative hours below $10,7,5,0$, and $-5^{\circ} \mathrm{C}$ for each sampling interval. In addition, for the three soiltemperature-measurement depths, mean and cumulative hours below 10, 7.5, 5, and $2.5^{\circ} \mathrm{C}$ were calculated. Months with no appreciable accumulation of low-temperature hours $(<25 \mathrm{~h}$ during the sampling interval) were omitted from the analysis. Thus, mean and cumulative temperature data from 7 of the 13 sampling intervals (mid-October through mid-April) were used for correlations with bacterial growth. Rainfall data were used to generate both mean and cumulative rainfall measures for each sampling interval.

Data analysis. For each sampling interval, ELISA scores were used to determine the frequency of detection of $X$. fastidiosa in host tissue, which was calculated as $100 \%-n \%$, where $n=$ percent of samples testing negative by ELISA for presence of the bacterium. Frequency of isolation of $X$. fastidiosa from host tissue was calculated for each sampling date by determining the percentage of cultures that exhibited typical colonies of $X$. fastidiosa. For each sampling interval, $\log _{10}$-transformed bacterial densities were expressed in two ways to determine which would correlate more strongly with the weather data. $\log _{10^{-}}$ transformed bacterial population density $\left(\log _{10} \mathrm{CFU} / \mathrm{g}\right)$ was calculated as the sum of 
all bacterial density measurements for a given sampling interval divided by the number $(n=18)$ of samples from which isolation was attempted during that interval. Censored $\log _{10}$-transformed bacterial population density $\left(\log _{10} \mathrm{CFU} / \mathrm{g}\right)$ was calculated as the sum of all bacterial density measurements for a given sampling interval divided by the number of cultures which showed characteristic growth of $X$. fastidiosa for that interval.

For both locations, the frequency of detection, frequency of isolation, and censored and uncensored bacterial densities were analyzed by analysis of variance (ANOVA) using the statistical package SAS (SAS Institute, Cary, NC), with location and tissue type as main factors. If no significant differences were found between the two locations, then the data from both locations were pooled. If there were significant differences between tissue types for any of the growth variables evaluated, then Fisher's Protected least significant difference (LSD) test was performed for each significant variable.

Linear correlations were performed using the statistical package SAS to determine whether mean or cumulative rainfall and mean or cumulative hours below the designated temperature thresholds were more strongly associated with the growth variables measured in this study. The temperature variable which was most strongly correlated with the measured growth variables was used for final correlations with specific growth variables.

Simple linear regressions for each combination of growth variable and air and soil temperature interval and rainfall measure were evaluated separately for roots and shoots, respectively, using PROC GLM in SAS software. From the regression of each combination, correlation coefficients $(r)$ and associated $P$ values were recorded. To observe overall seasonal shifts in bacterial detectability at the two locations, average monthly frequency of detection was plotted against sampling date for roots and shoots together. To observe seasonal shifts in bacterial cultivability and variation by tissue type, frequency of isolation from root samples and from shoot samples was plotted against sampling date.

Effects of low temperatures on bacterial populations in artificially inoculated sycamores under controlled conditions. Plant material selection. In three independent experimental trials, trees from putatively $X$. fastidiosa-resistant and -susceptible sycamore families were grown from cuttings in vector-free greenhouses from seed provided by Westvaco Corporation (Stamford, CT) (R. J. Rousseau, personal communication). These trees were approximately 2 years of age at the beginning of the experiment. In the first trial, 36 resistant and 36 susceptible sycamores were treated $(n=72)$. In the second trial, 33 resistant and 33 susceptible sycamores were treated $(n=66)$. In the third experimental trial, 30 resistant and 30 susceptible sycamores were treated $(n=60)$.

To prevent transmission by insect vectors during the study, all three experimental trials were conducted on host trees grown and maintained after inoculation within screened cages on greenhouse benches. Trees were placed in screen cages in a randomized fashion after transplanting and were re-randomized into the cages after inoculation.

Inoculum preparation and inoculation. For all three experimental trials, the sycamore strain of $X$. fastidiosa was isolated from a naturally infected sycamore on the University of Georgia campus in Athens. Inoculum was maintained at $28^{\circ} \mathrm{C}$ and subcultured on PW medium every 7 to 10 days, as soon as visible colony development was detected $(3,5)$. Before inoculation, subcultured isolates were grown on PW medium for 14 days. Plates were flooded with $3 \mathrm{ml}$ of sterile $\mathrm{PW}$ broth, lightly scraped to loosen colonies, collected into a sterile test tube, vortexed for 1 min, and the concentration adjusted by spectrophotometer to $10^{8}$ to $10^{9} \mathrm{CFU} / \mathrm{ml}$. At the time of each inoculation, inoculum density was confirmed by a series of five quantitative 10-fold dilutions in filtered PW broth and spread plating on PW medium. Confirmatory cultures were maintained at $28^{\circ} \mathrm{C}$, and colonies were counted for bacterial density estimates and randomly tested by ELISA to confirm pathogen identity as soon as visible colony growth was observed, after 10 to 14 days of incubation.

Inoculations were performed during mid- to late summer while trees were actively growing, using the pinprick method described by Hopkins (14). Trees were not watered for 1 week before inoculation to ensure optimal uptake of inoculum. At inoculation, trees were inspected for visible symptoms and all were found to be asymptomatic, although they were not tested for presence of the bacterium prior to inoculation. A $0.02-\mathrm{ml}$ drop of inoculum suspension or sterile, filtered PW broth was placed on a petiole attached to the main leader midway between the soil line and the tree's apex, approximately $60 \mathrm{~cm}$ above the soil line. An insulin needle (25 by $0.7 \mathrm{~mm}$ ) was used to pierce through the droplet and into the stem tissue of the main leader. As soon as the droplets were completely absorbed into the stems, inoculation points and a segment extending $2 \mathrm{~cm}$ above and below the inoculation point were marked with indelible pen for later sampling. Trees were maintained in the greenhouse screen cages for approximately 12 weeks after inoculation to allow time for systemic spread of $X$. fastidiosa.

Temperature treatment. In all experimental trials, half of the controls and half of the inoculated trees were arbitrarily selected near or after dormancy onset and placed in a dark cooler at $5^{\circ} \mathrm{C}$ to induce dormancy and to mimic low winter temperature conditions. Remaining trees were placed in a dark chamber within the greenhouse at $22^{\circ} \mathrm{C}$ to induce dormancy with no added low temperature stimulus. Resistant and susceptible cultivars were divided evenly between the two temperature treatments. Trees then were maintained under these conditions with biweekly watering for approximately 12 weeks.

Pathogen detection and isolation. After 3 months of temperature treatment, a $4-\mathrm{cm}$, approximately 5-g segment of the stem tissue containing each marked inoculation point was collected, plants were removed from the pots, soil was shaken from the roots, and plants were placed in large bags and temporarily stored at $5^{\circ} \mathrm{C}$. Stem sections containing inoculation points were surface disinfested in a solution of $9.5 \%$ ethanol and $1.05 \%$ sodium hypochlorite for $10 \mathrm{~min}$, then rinsed three times for 3 min in sterile, deionized water. Stem sections were squeezed with sterile pliers to extract approximately $0.3 \mathrm{ml}$ of sap from each stem section. Extract $(100 \mu \mathrm{l})$ was assayed immediately by ELISA to determine bacterial presence. An additional 100 $\mu \mathrm{l}$ was used in a five serial 10 -fold dilutions in PVPP extraction buffer. To estimate bacterial density within host tissue, 5 $\mu \mathrm{l}$ from each dilution was spread onto PW medium and plates were maintained at $28^{\circ} \mathrm{C}$ for 10 to 14 days, until visible colony growth was observed.

If the stem section containing the inoculation point tested positive for the presence of $X$. fastidiosa by ELISA, then the tree was retrieved from storage for further sampling. Each plant was divided into five parts based on position relative to the inoculation point: about $20 \mathrm{~cm}$ above the inoculation point, about $20 \mathrm{~cm}$ below the inoculation point, plant crown (approximately $5 \mathrm{~cm}$ above and below the soil line), coarse roots (5 to $10 \mathrm{~mm}$ diameter), and fine roots ( $\leq 2 \mathrm{~mm}$ diameter). Tissue ( 3 g) from each of these portions was prepared as described above for the inoculation points, except fine root samples. To obtain a representative sample, root balls were divided into quadrants and 1 to $3 \mathrm{~g}$ of fine roots was collected from each quadrant. After soil was rinsed from the fine root surfaces with tap water, they were placed in a petri dish, chopped into approximately 2 $\mathrm{cm}$ segments, and stirred lightly. Then, about $1 \mathrm{~g}$ of the fine roots was collected and surface disinfested as described above for stem sections. The roots were finely macerated (segments $\leq 2 \mathrm{~mm}$ ) in $3 \mathrm{ml}$ of sterile PVPP extraction buffer with a sterile razor blade. To prevent cross-contamination between samples, a fresh blade was used for each sample. The fine root suspension and extracted sap samples from larger stem and root tissues were assayed by ELISA and serial dilution plating, as previously described for stem sections. 
Bacterial presence was confirmed by both ELISA and culture on PW medium. To avoid overestimation by false positives, a conservative approach was taken when assessing ELISA results to assure that positive determinations were of populations that multiplied during treatment as opposed to remnants of inoculum. Only those samples with absorbance values of 0.95 or greater when read with a microtiter plate reader at $490 \mathrm{~nm}$ were considered to be positive. Culture assays were considered to be positive when characteristic $X$. fastidiosa colonies appeared on the PW medium after $\approx 10$ to 14 days. Characteristic colonies from each group of samples were arbitrarily selected and tested by ELISA to confirm identity of the pathogen. Visible colonies $(0.25$ to $1 \mathrm{~mm}$ in diameter) were counted and confirmed as previously described and bacterial density within the sample tissue was estimated. Bacterial densities were $\log _{10}$ transformed prior to analysis.

Data analysis. Frequency of detection and population density of $X$. fastidiosa in stem sections that included the inoculation point were analyzed separately. For each experimental trial, and for each combination of temperature treatment and host resistance, the frequency of detection in stem sections, including the inoculation point, was expressed as the percentage of samples (reps) that tested positive for the pathogen. The influence of treatment factors on the frequency of detection was determined by ANOVA using SAS software, with experimental trial, temperature treatment, and host resistance as main factors. Main effects and two-way treatment interactions were tested using the trial-temperature-host resistance interaction as an error term. $\log _{10}$-transformed bacterial population densities $\left(\log _{10}\right.$
$\mathrm{CFU} / \mathrm{g}$ ) were analyzed by ANOVA with experimental trial, temperature, and host resistance as main factors. If interactions between experimental trial and treatment factors were significant, then an ANOVA of bacterial population densities was performed separately for each experimental trial, with temperature and host resistance as main factors.

Frequency of detection and population density of $X$. fastidiosa in the different tissue samples from plants that had stem sections containing inoculation points which tested positive for the bacterium were subjected to further analysis. The influence of treatment factors on the frequency of detection was determined by ANOVA, with experimental trial, temperature treatment, host resistance, and plant part as main factors. Main effects and twoand three-way interactions were tested using the trial-temperature-host resistance-plant part interaction as an error term. Linear contrasts and Fisher's protected LSD were used to determine significant differences among plant parts. $\log _{10^{-}}$ transformed bacterial population densities $\left(\log _{10} \mathrm{CFU} / \mathrm{g}\right)$ were analyzed by ANOVA with experimental trial, temperature, host resistance, and plant part as main factors. If interactions between experimental trial and treatment factors were significant, then an ANOVA of bacterial population densities was performed separately for each experimental trial, with temperature, host resistance, and plant part as main factors. Linear contrasts and Fisher's protected LSD were used to determine significant differences among plant parts.

\section{RESULTS}

Effects of low temperatures on bacterial populations in naturally infected

Table 1. Correlation coefficients $(r)$ and associated I values (in parentheses) for linear correlations between detection and recovery of Xylella fastidiosa from sycamore shoot and root tissue sampled monthly and cumulative hours below air and soil temperature thresholds

\begin{tabular}{lllll}
\hline Temperature $\left({ }^{\mathbf{}} \mathbf{C}\right)$ & Detection $(\%)^{\mathbf{x}}$ & Isolation $(\%)^{\mathbf{y}}$ & Censored $^{\mathbf{z}}$ & Uncensored $^{\mathbf{z}}$ \\
\hline Air (shoot tissue) & & & & \\
10 & $-0.45(0.3156)$ & $-0.76(0.0463)$ & $-0.94(0.0014)$ & $-0.88(0.0085)$ \\
7 & $-0.42(0.3454)$ & $-0.75(0.0542)$ & $-0.94(0.0019)$ & $-0.88(0.0095)$ \\
5 & $-0.44(0.3283)$ & $-0.75(0.0542)$ & $-0.94(0.0016)$ & $-0.88(0.0082)$ \\
0 & $-0.44(0.3222)$ & $-0.76(0.0487)$ & $-0.94(0.0016)$ & $-0.90(0.0064)$ \\
-5 & $-0.60(0.1510)$ & $-0.79(0.0348)$ & $-0.96(0.0005)$ & $-0.91(0.0049)$ \\
Soil (root tissue) & & & & \\
10 & $-0.33(0.4667)$ & $-0.34(0.4557)$ & $-0.60(0.1530)$ & $-0.60(0.1523)$ \\
7.5 & $-0.31(0.4990)$ & $-0.31(0.4994)$ & $-0.59(0.1582)$ & $-0.60(0.1650)$ \\
5 & $-0.29(0.5309)$ & $-0.29(0.5345)$ & $-0.58(0.1612)$ & $-0.59(0.1750)$ \\
2.5 & $-0.25(0.5860)$ & $-0.25(0.5862)$ & $-0.55(0.1932)$ & $-0.56(0.1967)$ \\
\hline
\end{tabular}

${ }^{\mathrm{x}}$ Frequency of detection $=$ percentage of samples that tested positive for $X$. fastidiosa based on two replications of a commercially available double-antibody sandwich enzyme-linked immunosorbent assay (PathoScreen Xf peroxidase, Agdia, Elkhart, IN). Test was performed according to the manufacturer's instructions provided with the kit.

${ }^{\mathrm{y}}$ Frequency of isolation $=$ percentage of samples from which $X$. fastidios $a$ was isolated on periwinkle wilt (PW) medium.

${ }^{\mathrm{z}}$ Censored $\log _{10}$-transformed bacterial population density $\left(\log _{10} \mathrm{CFU} / \mathrm{g}\right)$ values were calculated as the sum of all bacterial density measurements for a given sampling interval divided by the number of samples from which successful isolations were grown on PW medium. Uncensored $\log _{10}$-transformed bacterial population density $\left(\log _{10} \mathrm{CFU} / \mathrm{g}\right)$ values were calculated as the sum of all bacterial density measurements for a given sampling interval divided by the number $(n=18)$ of samples from which isolation was attempted during that interval. sycamores in the field. No significant difference was found between Athens and Griffin locations for any of the bacterial growth variables measured: frequency of detection by ELISA, frequency of isolation on PW medium, and uncensored and censored bacterial densities. Therefore, data from the Athens and Griffin locations were pooled. ANOVA indicated that censored and uncensored bacterial densities isolated from roots and shoots were not significantly different at $P=0.05$. The mean, $\log _{10}$-transformed, censored bacterial density was estimated at $1.75 \log _{10} \mathrm{CFU} / \mathrm{g}$ and uncensored density was estimated at 1.41 $\log _{10} \mathrm{CFU} / \mathrm{g}$ for each month in which there was a considerable accumulation of belowthreshold temperatures. There were, however, significant differences between shoots and roots in terms of frequency of detection by ELISA $(P=0.0019)$ and frequency of isolation in culture $(P=0.0003)$ of $X$. fastidiosa. The mean frequency of ELISA detection of the bacterium in shoot samples was $54.3 \%$, in contrast to $22.1 \%$ in root samples. Similarly, the mean frequency of isolation and culture was significantly greater from shoot samples $(56.0 \%)$ than from root samples $(24.8 \%)$.

A much greater degree of correlation was found between bacterial population estimates and cumulative hours below selected temperature thresholds $(-0.96<r<$ $-0.25)$ than for mean hours below the selected temperature thresholds $(-0.50<r<$ $-0.00)$. As a result, temperature effects on viable bacteria were analyzed further in relation to cumulative hours below the designated temperature thresholds.

Bacterial populations in shoots were negatively correlated with cumulative hours below several of the designated temperature thresholds (Table 1), except for the regression of frequency of detection of $X$. fastidiosa, which showed no significant correlation. Regressions of bacterial populations in shoots on the five shoot-associated temperature thresholds revealed that frequency of isolation, censored bacterial density estimates, and uncensored bacterial densities were strongly correlated with cumulative hours below $-5^{\circ} \mathrm{C}(-0.79, P=$ $0.0348 ;-0.96, P=0.0005$; and $-0.91, P=$ 0.0049). Correlations between bacterial populations and cumulative hours below the other four temperature thresholds were weaker and less consistent (Table 1). Of the four variables evaluated, censored bacterial population density was most strongly correlated with cumulative hours below all temperature thresholds and had the greatest correlation of all comparisons $(r=$ $-0.96, P=0.0005)$ with cumulative hours below $-5^{\circ} \mathrm{C}$. In contrast to results obtained from shoot sample analysis, bacterial growth in roots did not show significant correlation with any of the temperature thresholds evaluated (Table 1).

Frequency of detection of the pathogen plotted over the 13 months of sampling 
revealed two peaks in the frequency of detection, one from December to February and another from July to September (Fig. 1). Differences in detection of the pathogen in root and shoot samples reveals that the two distinct peaks were more closely associated with bacterial presence in the stems than in roots (Fig. 2).

Bacterial growth variables did not correlate with mean rainfall for any sampling interval. Cumulative rainfall for each sampling interval was only weakly correlated with frequency of isolation $\left(r^{2}=0.571, P=\right.$ 0.049 ) and did not show a significant relationship to any other bacterial growth variable.

Effects of low temperatures on bacterial populations in artificially inoculated sycamores under controlled conditions. No spread of $X$. fastidiosa to noninoculated control trees occurred during any run of this experiment; therefore, data from controls were eliminated from further analysis.

There were no significant interactive effects between experimental trial and treatment factors on the frequency of detection of the bacterium in stem sections that included the inoculation point. Neither were there any significant differences between temperature treatments or host resistances in terms of frequency of detection in stem sections that included the inoculation point. Because no significant interactions were detected for either cold treatment or host resistance, results were pooled for further analysis. The mean frequency of detection of the bacterium in sycamore stem sections that included the inoculation point was $39.8 \%$ over all treatments and experimental trials. Bacterial population densities in stem sections that included the inoculation point differed significantly among experimental trials, but were not affected by either temperature treatment or host. In trials 1 and 3 , mean bacterial population densities in stem sections that included the inoculation point were 5.15 and $6.00 \log _{10} \mathrm{CFU} / \mathrm{g}$, respectively, and were significantly greater than the mean bacterial population density of $3.23 \log _{10}$ $\mathrm{CFU} / \mathrm{g}$ recorded in trial 2.

In those plants on which stem sections that included the inoculation point tested positive for the bacterium, frequency of detection in tissue samples was not significantly affected by either temperature treatment or host resistance. However, frequency of detection differed significantly among plant parts (Table 2). X. fastidiosa was detected most frequently in the apical stem portions $(66.3 \%)$ and least frequently in the fine roots $(1.3 \%)$. Frequency of detection of the bacterium was significantly greater in aboveground samples than in roots in all three trials $(P<0.0001, P=$ 0.0069 , and $P<0.0001$, respectively). Bacterial population density in portions of plants that tested positive for the bacterium at the inoculation point differed signifi- cantly among the three experimental trials; therefore, distributions of bacterial population densities within various host tissue samples were evaluated individually for each run of the study (Table 3 ). Bacterial densities were determined to be greatest in stem segments containing the inoculation point in all three trials; although, in trial 2, bacterial densities in apical and basal stem sections were not significantly different from the inoculation point. No $X$. fastidiosa was recovered from belowground samples in trial 2. In trial 1 , bacterial densities in apical and basal stem samples were significantly lower than in the stem section containing the inoculation point $\left(2.16\right.$ and $2.40 \log _{10}$ $\mathrm{CFU} / \mathrm{g}$, respectively) but were not significantly different from one another. In trial 3 , after the stem segment containing the inoculation point, bacterial density was greatest in the apical stem segment $(1.28$ $\log _{10} \mathrm{CFU} / \mathrm{g}$ ). In the third trial, however, bacterial density in basal stem and coarse

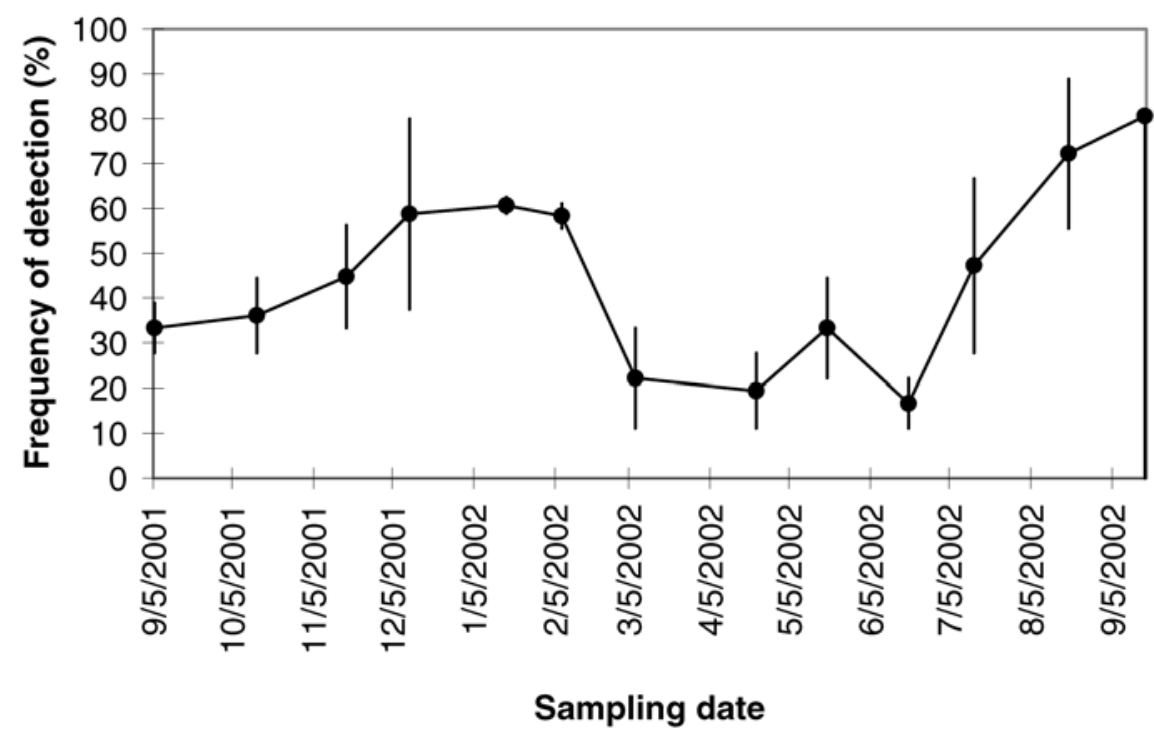

Fig. 1. Monthly fluctuation in detectability of Xylella fastidiosa in naturally infected sycamore from two locations in Georgia. Bacterial presence in stem and root extracts was determined by enzymelinked immunosorbent assay. Each data point represents 18 root and 18 shoot samples pooled from Athens and Griffin, GA sampling sites. Vertical lines indicate one standard deviation above and below the mean.
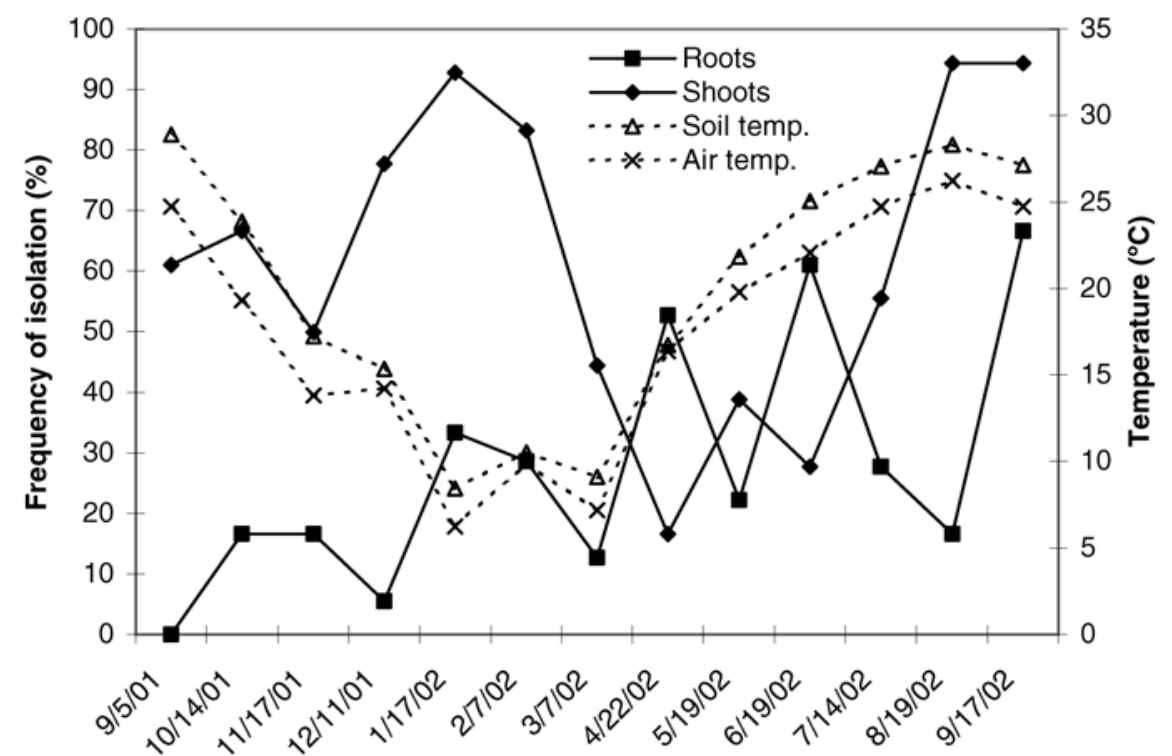

\section{Sampling date}

Fig. 2. Frequency of isolation of Xylella fastidiosa in naturally infected sycamore stems and shoots and mean minimum air and soil temperatures. Bacterial presence in stem and root extracts was determined by plating xylem sap samples onto periwinkle wilt agar medium. For roots and shoots, each data point represents the percentage of successful isolations from 18 root or 18 shoot samples from the pooled sampling sites in Athens and Griffin, GA. Air and soil temperature minima are pooled from Athens and Griffin sampling sites. 
root samples were not significantly different (Table 3).

\section{DISCUSSION}

Seasonal fluctuations in bacterial detectability and density have been observed in similar studies of sweet orange (Citrus sinensis (L.) Osbeck), grape (Vitis spp.), and red oak (Quercus rubra L.) infected with $X$. fastidiosa $(4,14,16)$. In grapevines, viable bacteria were undetectable until May or early June, then peaked in late summer, and remained detectable at declining levels until early winter (16). Chang and Walker found that $X$. fastidiosa could be isolated successfully from northern red oaks in Griffin, GA only from August until January (4), with maximum frequency of isolation during November. Frequency of detection of the bacterium in Florida citrus reached a peak in late summer similar to grape, but declined in the fall and increased again, attaining a second peak in December, January, and February (14). Our results show that the overall bacterial populations in sycamores sampled in Athens and Griffin, GA exhibit two distinct peaks that are most strongly influenced by seasonal shifts in bacterial density in infected stem tissue (Fig. 2). This is like the pattern reported by Hopkins in citrus, with a peak from December to February and a second from July to September. Hopkins suggested that host senescence may be a primary factor triggering the peak bacterial presence in fall, but this fails to explain the second, winter peak which occurs after hosts are dormant. Chang and Walker suggested that viable bacteria may increase in January and be carried upward from underground tissues at the end of winter (4). In another study of sharpshooter vectors in Florida citrus, Timmer and Lee showed that there are peaks in vector populations in Florida groves which are concurrent with peaks in populations of $X$. fastidiosa within citrus hosts (27). Perhaps, as Timmer and Lee suggest, large populations of highly efficient vectors may be responsible for rapid and considerable increases in bacterial density in sycamore as well. The springtime decline in detection frequency also may be related to accelerated host growth in spring; perhaps bacterial titer is reduced as the spring growth flush reduces the concentration of bacteria within the xylem sap.

Diseases caused by $X$. fastidiosa vary by host and often are classified by the types of symptoms they cause (24). Symptom expression has been linked to both host type and tissues in which bacterial multiplication occurs. In stunt diseases like phony peach, $X$. fastidiosa cells commonly accumulate in roots (1), whereas leaf scorch diseases like Pierce's disease of grape are most often characterized by bacterial accumulation in petioles and veins of symptomatic leaves (16). In dieback and decline diseases of forest and ornamental trees like sycamore and oak, $X$. fastidiosa has been reported to accumulate mainly in the trunk and stems, especially in those sectors showing typical symptoms $(2,20,22,24)$. In our study, we detected the pathogen more frequently in stem tissues than roots by both isolation and ELISA for most of the

Table 2. Position relative to the inoculation point and mean frequency of detection of Xylella fastidiosa by enzyme-linked immunosorbent assay in various tissues of 2-year-old sycamore trees with confirmed infection at inoculation points

\begin{tabular}{llc}
\hline Plant part & Relative sample position & Frequency of detection $(\%)^{\mathbf{z}}$ \\
\hline Leader apex & $\approx 20 \mathrm{~cm}$ above inoculation point & $66.3 \mathrm{~b}$ \\
Inoculation point & $\approx 60 \mathrm{~cm}$ above soil line & $100.0 \mathrm{a}$ \\
Basal stem & $\approx 20 \mathrm{~cm}$ below inoculation point & $39.0 \mathrm{c}$ \\
Crown & Soil line $\pm 5 \mathrm{~cm}$ & $11.3 \mathrm{~d}$ \\
Coarse roots & 5 to $10 \mathrm{~mm}$ in diameter & $41.1 \mathrm{c}$ \\
Fine roots & $<2 \mathrm{~mm}$ in diameter & $1.3 \mathrm{~d}$ \\
\hline
\end{tabular}

${ }^{\mathrm{z}}$ Means are based on data pooled over treatments and experimental trials. Means followed by the same letter are not significantly different based on Fisher's Protected least significant difference test $(P>0.05)$.

Table 3. Population density of Xylella fastidiosa in 2-year-old sycamore trees inoculated with the pathogen and maintained at 5 or $22^{\circ} \mathrm{C}$ for 12 weeks

\begin{tabular}{lccc}
\hline & \multicolumn{3}{c}{ Bacterial population density $\left(\log _{\mathbf{1 0}} \mathbf{C F U} / \mathbf{g}\right)^{\mathbf{z}}$} \\
\cline { 2 - 4 } Plant part & Trial 1 & Trial 2 & Trial 3 \\
\hline Leader apex & $2.16 \mathrm{~b}$ & $1.41 \mathrm{a}$ & $1.28 \mathrm{~b}$ \\
Inoculation point & $5.15 \mathrm{a}$ & $3.23 \mathrm{a}$ & $6.00 \mathrm{a}$ \\
Basal stem & $2.40 \mathrm{~b}$ & $1.41 \mathrm{a}$ & $0.36 \mathrm{~cd}$ \\
Crown & $0.25 \mathrm{c}$ & $0.00 \mathrm{~b}$ & $0.00 \mathrm{~d}$ \\
Coarse roots & $0.00 \mathrm{c}$ & $0.00 \mathrm{~b}$ & $0.61 \mathrm{c}$ \\
Fine roots & $0.00 \mathrm{c}$ & $0.00 \mathrm{~b}$ & $0.00 \mathrm{~d}$ \\
\hline
\end{tabular}

$\overline{{ }^{\mathrm{z}} \text { Results for both temperature treatment and host resistance groups are pooled, because no significant }}$ differences were detected among them. Bacterial population densities in each column followed by the same letter are not significantly different based on Fisher's Protected least significant difference test $(P>0.05)$.

year, even during winter months when the pathogen population was most likely to survive and accumulate in soil-insulated root xylem, as suggested by Chang and Walker (4). Reduced frequency of bacterial detection within root tissues also may be explained by arbitrary collection of root samples; stems initially were selected during active growth on the basis of symptom presence, whereas roots were selected by meeting criteria of sufficient diameter and accessibility. In their study, Aldrich et al. (1) provide evidence that the bacteria are not uniformly distributed within the roots of infected peach trees and suggest that likelihood of detection in roots may be increased by selecting sampling size on the basis of probability of host infection in the sampling area. In our research, sampling a larger number of roots might have increased the frequency of detection of $X$. fastidiosa.

A conservative approach was taken in assessing positive detection by ELISA in our research. Only those samples which gave strong positive reactions to serological assay (readings of 0.95 or greater at $490 \mathrm{~nm}$ absorbance) were considered positive. Although this heightens the certainty of accurate positives, it also may have resulted in underestimation of the presence of $X$. fastidiosa within the trees tested. Research relating ELISA absorbance readings to growth curves for $X$. fastidiosa would be most useful in helping to resolve questions of bacterial presence and population density, particularly in situations where latent infections can contribute significantly to the reservoir of inoculum (24).

Results of our analysis of low-temperature thresholds indicate that air temperatures below $-5^{\circ} \mathrm{C}$ are associated with reduced bacterial viability in sycamore shoots. This finding is consistent with previous reports of therapeutic effects of low temperatures on infected grapevines (22). In his research, Purcell found that multiple exposures of 1.5 to $24 \mathrm{~h}$ to temperatures ranging from -12 to $0^{\circ} \mathrm{C}$ greatly enhanced the likelihood of survival of inoculated, symptomatic grapevines. Both sets of results suggest that $X$. fastidiosa populations may be reduced directly by exposure to suboptimal temperatures or indirectly by freezing or dehydration of the infected xylem tissues (22). These findings also may explain the lack of correlation between root tissue and soil temperatures in this study. Soil temperatures below $2.5^{\circ} \mathrm{C}$ were seldom observed at 5 and 10 $\mathrm{cm}$ below the soil surface at either location; whereas, at a $20-\mathrm{cm}$ depth, the temperature never reached below $2.5^{\circ} \mathrm{C}$. In fact, at a 20-cm depth, only $347 \mathrm{~h}$ accumulated below the $5^{\circ} \mathrm{C}$ threshold during the 13 months in which temperature was monitored. These warm soils may have insulated bacteria within roots or failed to reach temperatures low enough for long 
enough to have a significantly deleterious effect on populations of viable bacterial cells. This hypothesis is supported by a recent study of temperature-dependent growth and survival of $X$. fastidiosa both in vitro and in infected, containerized grapevines (8). Although in vitro populations did not grow below $12^{\circ} \mathrm{C}$ and minimum threshold temperature for bacterial growth in planta was determined to be between 17 and $25^{\circ} \mathrm{C}$, populations of $X$. fastidiosa in plants held at $5^{\circ} \mathrm{C}$ declined slowly and still exceeded $6 \log _{10} \mathrm{CFU} / \mathrm{g}$ after 18 days. Bacterial populations in infected grapevines held at $10^{\circ} \mathrm{C}$ declined very slightly $\left(-1 \log _{10} \mathrm{CFU} / \mathrm{g}\right.$ ) over the first 9 days, but stabilized over the next 9 days to a level comparable with that present before temperature treatment was initiated (8). These results suggest that, although bacterial multiplication may be reduced or retarded at suboptimal temperatures, enough viable cells may remain for populations to remain stationary or suffer only mild reductions. Lack of correlation between recovery of $X$. fastidiosa from sycamore roots and cumulative hours below any of the temperature thresholds examined indicates that factors other than low soil temperature probably influence viability of $X$. fastidiosa in sycamore roots. Successful detection by ELISA and recovery of the pathogen in culture indicates that $X$. fastidiosa cells may be present in host root systems throughout periods of dormancy and active growth. Presence of cultivable cells during the coldest times of the year at both locations provides evidence that this pathogen may be able to overwinter within the root xylem of infected hosts and suggests that cells may be translocated to distal limbs in spring.

No significant response to low-temperature treatment at $5^{\circ} \mathrm{C}$ was observed in resistant or susceptible plants. Although it generally is accepted that the geographical distribution of $X$. fastidiosa is limited at the northern end of its range by low winter temperatures $(22,24)$, formal studies of seasonal and temperature-driven fluctuation in populations of $X$. fastidiosa within host plants have yielded variable results. In a study of grapevines infected with $X$. fastidiosa and exposed to 5 months of winter conditions at a variety of cold climates in California, researchers found that vines maintained in more extreme environments exhibited near $100 \%$ reduction in symptoms and had no recoverable populations of $X$. fastidiosa after 6 months (23). However, Purcell indicated that the weak correlation between average minimum temperature and the percentage of plants "cured" of disease suggested that factors additional to average minimum temperature might be at work in limiting disease incidence (23). Similar growth chamber research on cold-treated bare-root and containerized grapevines indicated that infection by $X$. fastidiosa might be amelio- rated by exposing hosts to low temperatures $(8,22)$. Purcell reported that multiple exposures of container-grown and bareroot grapevines for 1.5 to $24 \mathrm{~h}$ to temperatures ranging from -12 to $0^{\circ} \mathrm{C}$ greatly enhanced the likelihood of symptom remission in inoculated, symptomatic grapevines as the number and severity of cold treatments increased (22). In a study of temperature-dependent growth and survival of $X$. fastidiosa in cold-treated, containerized grapevines (8), Feil and Purcell determined that the in planta minimum threshold temperature for growth was between 17 and $25^{\circ} \mathrm{C}$. In another study (7), Feil and Purcell discovered a significant correlation between lateness in the growing season of host inoculation and reduced multiplication and survival of bacterial populations in current and subsequent seasons. Our inoculation dates tended to be later in the growing season; therefore, it is possible that bacterial populations did not establish well due to predormancy alterations in host xylem chemistry, such as increases in levels of dormancy-driven bacterial growth inhibitors.

Although a response to cold treatment was not observed in our study, the lack of response was not entirely unexpected. In a study of $X$. fastidiosa in naturally infected citrus groves in Florida, frequency of detection of bacteria within host plants was greatest from June to September and from December to February (15). It is likely that, in the milder Florida climate, winter temperature minima are not low enough to cause significant pathogen mortality, unlike the response observed in grapevines by Purcell in the colder climes of the $\mathrm{Pa}$ cific northwest (23).

Additionally, in the field component of this study, we found that air temperatures below $-5^{\circ} \mathrm{C}$ were best associated with limiting bacterial multiplication in host tissue. These findings are consistent with reports that "bacterial leaf scorch diseases on ornamental and forest trees appear to extend into cooler winter climates than [does] Pierce's disease or phony peach disease" (24). Kostka et al. (17) successfully isolated the causal bacterium from oak trees as far north as New York and Pennsylvania, and Sherald et al. (26) described leaf scorch on red maple in northern Virginia. Mechanisms for survival of $X$. fastidiosa in forest and ornamental trees in cooler winter climates are not well understood. However, it has been suggested that, during winter months, pathogen populations may survive and accumulate in soilinsulated root xylem (4), and it also is possible that strains of $X$. fastidiosa infecting more northerly forest and ornamental trees have become adapted to lower temperatures. Whatever the survival mechanisms may be, there is strong evidence to suggest that the low-temperature treatment we imposed may not have been cold enough to elicit a significant decline in bacterial titer within the sycamore host tissue, although more expanded trials are needed to determine the exact mechanisms of bacterial survival in planta.

No significant host resistance response was observed in the putatively resistant and susceptible sycamore progeny tested. Although failure to observe a significant resistance response suggests that putative resistance may be an artifact, it is important to note that the putative resistance of sycamores used in this study was based on 17 years of observations of ortets and parental families, which should not be discounted without more detailed examination (R. J. Rousseau, personal communication). Although specific mechanisms for host resistance are not well understood in sycamore, resistance may be based in tolerance of bacterial infection, differential physiology, or biochemical factors for which our examination was not structured. To determine the existence and nature of host resistance, it is necessary to construct a study wherein symptoms can be observed in conjunction with assays for presence and populations of $X$. fastidiosa.

Examinations of bacterial presence and distribution through the host indicate that $X$. fastidiosa infections of sycamore tend to remain localized in aerial portions of the plant, but that some spread to crown and root xylem does occur. This is consistent with reports that, in dieback and decline diseases of ornamental and forest trees, $X$. fastidiosa accumulates mainly in trunks and stems, around the point of inoculation or vector feeding. For example, Barnard et al. reported greater frequency of detection of the pathogen in symptomatic leaf, petiole, and stem tissues than in similar asymptomatic tissues (2). Further, Hill and Purcell, in two of their $X$. fastidiosa population and vector transmission studies $(13,25)$, suggested that efficiency of acquisition of the bacterium by insect vectors might be reduced as distance of vector feeding from the site of original mechanical inoculation increased and that, in some nonproliferative hosts, bacteria may fail to spread beyond xylem immediately adjacent to the inoculation point. Additionally, bacteria either may not have had sufficient time to reach populations large enough for full systemic movement before cold treatment was imposed, or simply may have lacked the strong virulence traits necessary for extensive host colonization.

Based on our results, the primary direction for bacterial spread was acropetal, although basipetal movement of the bacterium also was observed. This type of distribution is expected in a xylem-mobile bacterium, where spread should be greatest in the direction of the transpiration stream. Mechanisms of spread to distal downstream regions are not well understood, although lateral movement through breached pit membranes has been observed ultrastructurally. Additionally, a functional 
genetic analysis of the $X$. fastidiosa type II secretion system has suggested the potential to produce cell-degrading gene products, including endoglucanase, polygalacturonase, and several proteases (6), which might break down pit membranes and facilitate bacterial movement into adjoining vessels. It also is possible that bacteria were present in roots at the time of inoculation, because health assessments for host plants made during inoculation were based on visual symptoms only. Presence of bacteria in roots, regardless of the transport mechanism, provides evidence that roots may provide a sheltered environment where bacteria may survive and develop into early-season inoculum reservoirs even before vector populations become active. Further research should be aimed at identifying the degree to which bacterial populations overwintering in roots contribute to early-season infection, which has been determined to lead to the greatest losses in subsequent seasons (8).

\section{LITERATURE CITED}

1. Aldrich, J. H., Gould, A. B., and Martin, F. G. 1992. Distribution of Xylella fastidiosa within the roots of peach. Plant Dis. 76:885-888.

2. Barnard, E. L., Ash, E. C., Hopkins, D. L., and McGovern, R. J. 1998. Distribution of Xylella fastidiosa in oaks in Florida and its association with growth decline in Quercus laevis. Plant Dis. 82:569-572.

3. Chang, C. J., and Donaldson, R. C. 2000. Nutritional requirements of Xylella fastidiosa, which causes Pierce's disease in grapes. Can. J. Microbiol. 46:29-293.

4. Chang, C. J., and Walker, J. T. 1988. Bacterial leaf scorch of northern red oak: Isolation, cultivation, and pathogenicity of a xylem-limited bacterium. Plant Dis. 72:730-733.

5. Davis, M. J., Purcell, A. H., and Thomson, S. V. 1980. Isolation medium for the Pierce's disease bacterium. Phytopathology 70:734-739.

6. Dow, J. M., and Daniels, M. J. 2000. Xylella genomics and bacterial pathogenicity to plants. Yeast 17:263-271.

7. Feil, H., Feil, W. S., and Purcell, A. H. 2003. Effects of date of inoculation on the withinplant movement of Xylella fastidiosa and persistence of Pierce's disease within field grapevines. Phytopathology 93:244-251.

8. Feil, H., and Purcell, A. H. 2001. Temperaturedependent growth and survival of Xylella fastidiosa in vitro and in potted grapevines. Plant Dis. 85:1230-1234.

9. French, W. J., Christie, R. G., and Stassi, D. L. 1977. Recovery of rickettsialike bacteria by vacuum infiltration of peach tissues affected with phony disease. Phytopathology 67:945948.

10. Greene, T. A., and Lowe, W. J. 1992. Changes in the pattern of genetic variability over time in American sycamore and the implication for early selection. Can. J. For. Res. 22:713-717.

11. Hearon, S. S., Sherald, J. L., and Kostka, S. J. 1980. Association of xylem-limited bacteria with elm, sycamore, and oak leaf scorch. Can. J. Bot. 58:1986-1993.

12. Hill, B. L., and Purcell, A. H. 1995. Multiplication and movement of Xylella fastidiosa within grapevine and four other plants. Phytopathology 85:1368-1372.

13. Hill, B. L., and Purcell, A. H. 1997. Populations of Xylella fastidiosa in plants required for transmission by an efficient vector. Phytopathology 87:1197-1201.

14. Hopkins, D. L. 1980. Use of the pin-prick inoculation technique to demonstrate variability in virulence of the Pierce's disease bacterium. Pages 177-180 in: Proc. VIIth Int. Conf. Viruses Grapevine (ICVG), Niagara Falls, Canada.

15. Hopkins, D. L., Bistline, F. W., Russo, L. W., and Thompson, L. M. 1991. Seasonal fluctuation in the occurrence of Xylella fastidiosa in root and stem extracts from Citrus with blight. Plant Dis. 75:145-147.

16. Hopkins, D. L., and Thompson, C. M. 1984. Seasonal concentration of the Pierce's disease bacterium in 'Carlos' and 'Welder' muscadine grapes compared with 'Schuyler' bunch grape. HortScience 19:419-420.

17. Kostka, S. J., Tattar, T. A., and Sherald, J. L. 1986. Elm leaf scorch: Abnormal physiology in American elms infected with fastidious, xy- lem-inhabiting bacteria. Can. J. For. Res. 16:1088-1091.

18. Land, S. B., Jr. 1982. Genetic Selection of American Sycamore for Biomass Production in the Mid-South. Short Rotation Woody Crops Program, Oak Ridge National Laboratory, Oak Ridge, TN.

19. Leininger, T. D., Solomon, J. D., Wilson, A. D., and Schiff, N. M. 1999. A guide to major insects, diseases, air pollution injury, and chemical injury of sycamore. Gen. Tech. Rep. SRS 28. U. S. Dep. Agric. For. Serv. South. Res. Stn. Asheville, NC.

20. McGovern, R. J., and Hopkins, D. L. 1994. Association of Xylella fastidiosa with leaf scorch and decline of live oak in Florida. Plant Dis. 78:924.

21. National Park Service Center for Urban Ecology. 1993. Bacterial leaf scorch of landscape trees. Cent. Urban Ecol. Inf. Bull. National Park Service, Washington, DC.

22. Purcell, A. H. 1977. Cold therapy of Pierce's disease of grapevines. Plant Dis. Rep. 61:514518.

23. Purcell, A. H. 1980. Environmental therapy for Pierce's disease of grapevines. Plant Dis. 64:388-390.

24. Purcell, A. H., and Hopkins, D. L. 1996. Fastidious xylem-limited bacterial plant pathogens. Annu. Rev. Phytopathol. 34:131-151.

25. Purcell, A. H., and Saunders, S. R. 1999. Fate of Pierce's disease strains of Xylella fastidiosa in common riparian plants in California. Plant Dis. 83:825-830.

26. Sherald, J. L., Wells, J. M., Hurtt, S. S., and Kostka, S. J. 1987. Association of fastidious, xylem-inhabiting bacteria with leaf scorch in red maple. Plant Dis. 71:930-933.

27. Timmer, L. W., Lee, R. F., Allen, J. C., and Tucker, D. P. H. 1982. Distribution of sharpshooters in Florida citrus groves. Environ. Entomol. 11:456-460.

28. Wells, J. M., Raju, B. C., Hung, H. Y., Weisburg, W. G., Mandelco-Paul, L., and Brenner D. J. 1987. Xylella fastidiosa gen. nov., sp. nov.: Gram-negative, xylem-inhabiting, fastidious plant bacteria related to Xanthomonas spp. Int. J. Sys. Bacteriol. 37:136-143.

29. Wells, O. O., and Toliver, J. R. 1987. Geographic variation in sycamore (Platanus occidentalis L.). Silvae Genet. 36:154-159. 